\title{
KOMUNIKACJA BANKU CENTRALNEGO Z RYNKIEM A STABILIZOWANIE OCZEKIWAŃ INFLACYJNYCH
}

\section{WPROWADZENIE}

Współczesna polityka pieniężna powinna być skoncentrowana na stabilizowaniu oczekiwań inflacyjnych. Wynika to bezpośrednio z teorii ekonomii. Inflacja ma charakter antycypacyjny, jej poziom w okresie $t$ zależy od oczekiwań inflacyjnych na okres kolejny oraz od luki popytowej. Takie rozumienie natury inflacji wymusiło na bankach centralnych konieczność koncentracji polityki monetarnej na stabilizowaniu oczekiwań inflacyjnych. Przekłada się to na wybory na płaszczyźnie strategicznej polityki: obarczenie banku centralnego celem inflacyjnym jako celem nadrzędnym, podawanie do publicznej wiadomości numerycznego poziomu celu, który ma stanowić kotwicę nominalną, zastępując $\mathrm{w}$ tej roli cel pośredni związany $\mathrm{z}$ tradycyjną strategia polityki pieniężnej czy wdrożenie jakościowych standardów polityki pieniężnej. Dążenie do stabilizacji oczekiwań inflacyjnych, doprowadziło między innymi do szczególnej dbałości o przejrzystość działań banku centralnego. Realizacja przejrzystości jest uruchomienie narzędzi komunikacji z rynkiem. Polityka pieniężna prowadzona $\mathrm{w}$ ramach strategii celu inflacyjnego powinna być przewidywalna, co zapewnić ma właśnie odpowiednia komunikacja z otoczeniem gospodarczym.

Dodatkowym ograniczeniem narzuconym na bank centralny jest niemożność natychmiastowego wpływu na cel nadrzędny. Władze monetarne najczęściej wskazuja, że horyzont efektywnej transmisji monetarnej to okres po upływie 4-6 kwartałów od zmiany stóp procentowych. Dlatego bank centralny potrzebuje nie tylko narzędzi i danych służących do oceny sytuacji bieżącej, ale nade wszystko - prognoz inflacji. Wspomagają one jego proces decyzyjny, a z punktu widzenia komunikacji z rynkiem mają wspierać kotwiczenie oczekiwań inflacyjnych. Wyjaśnia to szczególne miejsce prognoz inflacji i innych narzędzi komunikacji sygnalizujących intencje w polityce pieniężnej (na przykład nastawienie, bilans ryzyka inflacji) wśród instrumentów komunikacji z rynkiem. Prognoza inflacji może być sporządzana i publikowana z wykorzystaniem różnych metod, co powinno wpływać na stopień realizacji jej funkcji - możliwość kotwiczenia oczekiwań inflacyjnych.

Niniejszy artykuł skupiać się ma właśnie na wpływie banku centralnego na oczekiwania inflacyjne podmiotów gospodarczych poprzez dobór narzędzi komunikacji z rynkiem - w szczególności sposobu komunikowania intencji 
władz monetarnych. Zawierał będzie przegląd badań empirycznych i teoretycznych na ten temat. Jego celem naukowym jest dokonanie analizy związków między sposobem ogłaszania intencji w polityce pieniężnej a stabilizowaniem oczekiwań inflacyjnych podmiotów gospodarczych.

Realizacji tego celu podporządkowana jest struktura tekstu. Jego druga część poświęcona będzie sposobom komunikowania intencji przez banki centralne. Część trzecia scharakteryzuje prognozy inflacji jako narzędzia mające wywierać wpływ na oczekiwania podmiotów gospodarczych. W części czwartej zaprezentowane zostaną wyniki analiz teoretycznych i badań empirycznych dotyczących współzależności między prognozami inflacji a oczekiwaniami inflacyjnymi podmiotów gospodarczych. Rozważania zakończy podsumowanie.

W tym miejscu poczynić należy jeszcze jedną uwagę. Współczesna teoria ekonomii, z której wyprowadza się antycypacyjny charakter inflacji, jest szeroko akceptowana, ale i powszechnie krytykowana ${ }^{1}$. Krytyka szkoły głównego nurtu rozwijała się wraz ze jej ewolucją. W ostatnich latach zaobserwować można jednak szczególnie intensywne poszukiwanie rozwiązań dla polityki pieniężnej $^{2}$. Początek drugiego dziesięciolecia XXI w. to okres, w którym nieznany jest jeszcze nowy konsensus. Nie będzie on jednak prawdopodobnie odrzucał myśli głównego nurtu. Banki centralne także jeszcze uwikłane sa w działania mające przeciwdziałać skutkom kryzysu gospodarczego. Ze względu na fakt, że nowe oblicze polityki monetarnej jest kwestią przyszłości, w tekście tym dominuja odwołania do dotychczasowych rozwiązań.

\section{KOMUNIKOWANIE INTENCJI BANKU CENTRALNEGO}

Przejrzystości polityki pieniężnej jest w zasadzie standardem. Jej zakres jest systematycznie rozszerzany. Ta praktyka nie jest spójna z wynikami badań naukowych dotyczących optymalnego poziomu otwartości banku centralnego nie ma konsensusu określającego, jaki poziom przejrzystości wystarczy społeczeństwu, a jaki jest optymalny z punktu widzenia banku centralnego. Zwiększanie zakresu przejrzystości jest sprawą wyboru banków centralnych większość niezwłocznie ujawnia informację o zmianie instrumentów polityki, jednocześnie to uzasadniając. Większość banków centralnych wdrażających strategię celu inflacyjnego ujawnia także, na jakiej podstawie decyzje sa podejmowane. Najwięcej kontrowersji budzi jednak sygnalizowanie intencji władz monetarnych. Banki centralne maja tu do wyboru kilka

\footnotetext{
${ }^{1}$ Krytyka dotyczy wielu aspektów, takich jak brak dowodów empirycznych, niestabilność w czasie równania inflacji, nierealistyczne założenia (racjonalne oczekiwania, reprezentatywny agent), brak kosztów dezinflacji w modelu. Przegląd piśmiennictwa na ten temat zawiera tekst M. Szyszko, Wspótczesna teoria ekonomii a polityka pieniężna, w: eadem, W. Przybylska-Kapuścińska (red.), Wyzwania wspótczesnej polityki pieniężnej, Difin, Warszawa 2012. Kompleksową krytyczną analizę myśli głównego nurtu zawiera monografia: I. Bludnik, Neokeynesizm. Analiza krytyczna, Wydawnictwo Uniwersytetu Ekonomicznego w Poznaniu, Poznań 2010.

${ }^{2}$ Czego przykładem niech będzie odejście od tzw. konsensusu z Jackson Hole i obarczenie banków centralnych explicite celem w postaci stabilności finansowej. Bank centralny ma przyczyniać się do wspierania stabilności znacznie bardziej aktywnie, niż tylko utrzymując niski i stabilny poziom inflacji.
} 
możliwości: opis perspektyw inflacji, publikowanie nastawienia w polityce, ocenę bilansu ryzyka inflacji czy wreszcie publikację prognoz inflacji i ewentualnie spójnej z nią ścieżki stóp procentowych ${ }^{3} \mathrm{w}$ różnych wariantach. Ich istotę opisano w tabeli 1.

\section{Tabela 1}

Sposoby sygnalizowania intencji władz monetarnych

\begin{tabular}{|c|c|}
\hline Sposób & Istota \\
\hline Perspektywy inflacji & $\begin{array}{l}\text { Bilans czynników wpływajacych na kształtowanie się przyszłej } \\
\text { inflacji. Jakościowy opis sytuacji ogólnogospodarczej i jej } \\
\text { wpływu na inflację. Obok oceny sytuacji bieżącej, perspektywy } \\
\text { moga uwzględniać również prognozy. Zazwyczaj informacja } \\
\text { dotyczy relacji najbardziej prawdopodobnego w ocenie banku } \\
\text { centralnego poziomu przyszłej inflacji do celu inflacyjnego. } \\
\text { Prezentowane w dokumentach zawierających szersza ocenę } \\
\text { sytuacji gospodarczej i polityki pieniężnej, jak raporty o inflacji } \\
\text { lub womunikatach po posiedzeniach komitetów monetarnych. }\end{array}$ \\
\hline $\begin{array}{l}\text { Nastawienie polityki } \\
\text { monetarnej }\end{array}$ & $\begin{array}{l}\text { Trzy możliwości: ekspansywne, neutralne, restrykcyjne. Na- } \\
\text { stawienie neutralne oznacza, że prawdopodobieństwo obniżenia } \\
\text { stóp procentowych jest równe prawdopodobieństwu podwyżki. } \\
\text { Ogłaszane po posiedzeniach komitetu monetarnego. }\end{array}$ \\
\hline Prognoza inflacji & $\begin{array}{l}\text { Prezentacja ilościowa (wykres wachlarzowy) ścieżki centralnej } \\
\text { z szerszym komentarzem. W zależności od rodzaju prognozy } \\
\text { upubliczniana (opisowo lub liczbowo) może być ścieżka stóp } \\
\text { spójna z prognoza. Prezentowane w dokumentach zawiera- } \\
\text { jących szerszą ocenę sytuacji gospodarczej i polityki pieniężnej, } \\
\text { jak raporty o inflacji. }\end{array}$ \\
\hline $\begin{array}{l}\text { Bilans ryzyka dla } \\
\text { prognozy inflacji }\end{array}$ & $\begin{array}{l}\text { Uzupełnia prezentacje prognozy inflacji. Ryzyko odchyla się } \\
\text { w górę, gdy czynniki wewnętrzne i zewnętrzne wpływajace na } \\
\text { inflację kształtują się w taki sposób, że bardziej prawdopodobne } \\
\text { jest, iż faktyczna inflacja będzie wyższa od ścieżki centralnej, } \\
\text { niż to, że będzie niższa. Ze względu na niższą częstotliwość } \\
\text { sporządzania prognoz niż posiedzeń komitetów monetarnych } \\
\text { pozwala na odnoszenie się do wyniku prognozy także w tych } \\
\text { miesiącach, gdy nie jest najbardziej aktualna. }\end{array}$ \\
\hline
\end{tabular}

Źródło: opracowanie własne.

Perspektywy inflacji zostały w zasadzie zastąpione przez publikację prognoz inflacji banku centralnego. Władze monetarne ograniczały się do perspektyw wówczas, gdy nie dysponowały prognozą inflacji lub gdy nie chciały jej ujawniać bezpośrednio. Ta druga możliwość wiązała się z krótkim doświadczeniem w zakresie prognozowania inflacji na podstawie modelu

${ }^{3}$ Prognoza i ścieżka stóp nie tylko wskazują na intencje władz monetarnych, przyczyniając się do stabilizowania oczekiwań inflacyjnych, lecz także stanowią przesłankę podejmowania decyzji przez komitet monetarny. 
strukturalnego. Co za tym idzie, prognoza obarczona być mogła znacznym błędem. Bilans czynników wpływających na kształtowanie się przyszłej inflacji $\mathrm{w}$ formie zbliżonej do perspektyw inflacji może być również prezentowany równolegle z prognozą inflacji, co ma związek z tym, że prognozy ukazują się z mniejszą częstotliwością, niż obraduje komitet monetarny.

Nastawienie w polityce pieniężnej stanowi syntetyczną formę wskazywania prawdopodobnej przyszłej zmiany stóp procentowych. Wykorzystanie tego instrumentu wymaga pewnej sprawności w komunikacji banku centralnego. Sytuacja, gdy na przykład przy nastawieniu neutralnym ma miejsce cykl obniżek stóp procentowych, jest kontestowana przez uczestników rynku.

Współcześnie najbardziej rozpowszechnioną formą transparentności w zakresie komunikowania intencji banku centralnego jest publikacja prognoz inflacji. W przeciwieństwie do dwóch poprzednich form stanowią one nie tylko wynik deliberacji członków komitetu monetarnego, ale również przesłankę podejmowania decyzji dotyczących stóp procentowych. Od rodzaju prognozy zależy możliwość jeszcze dokładniejszego naprowadzania rynku na kolejny ruch władz monetarnych. Najsilniejszą deklaracją, jaką może złożyć komitet monetarny, jest publikacja wykresu wachlarzowego ze ścieżką stóp procentowych spójną $\mathrm{z}$ prognozą. Niekiedy banki centralne uzupełniaja publikacje prognoz opisowa informacja o bilansie ryzyka prognozy.

Zaprezentowane sposoby ogłaszania intencji banku centralnego ewoluuja. Bank centralny może testować ich skuteczność oraz rozwijać narzędzia umożliwiające usprawnienie komunikacji z rynkiem dotyczącej intencji. Przykładem niech będzie sposób komunikowania intencji przez Narodowy Bank Polski. W czerwcu 1999 r. ukazał się pierwszy „Raport o inflacji” obejmujący 1998 r. Opublikowano w nim perspektywy inflacji. Pierwszą projekcję zaprezentowano w „Raporcie o inflacji. Sierpień 2004”. Jednocześnie do końca 2005 r. każdorazowo po posiedzeniu decyzyjnym informowano rynek o nastawieniu w polityce pieniężnej. Praktykę tę zastąpiono z początkiem 2006 r. oceną bilansu czynników wpływających na kształtowanie się przyszłej inflacji. Jednocześnie w 2009 i 2010 r. informowano, że NBP rozpoczął prace nad publikacja ścieżki stóp. W połowie 2010 r. zrezygnowano jednak z informacji o rozkładzie ryzyka w komunikacie dla rynku. Co więcej, prezes NBP ogłosił, że prace nad publikację ścieżki stóp zostają zawieszone.

Dotychczas omówiono tylko syntetyczne sposoby sygnalizowania intencji banku centralnego, co jest spójne z celem niniejszego opracowania. Pamiętać należy jednak, że bank centralny ujawnia swoje zamierzenia również poprzez opisowe, jakościowe wyjaśnianie decyzji czy publikowanie opisów dyskusji podczas posiedzenia komitetu monetarnego.

Podsumowując przegląd sposobów przedstawiania intencji banku centralnego, należy podkreślić, że jedne oddziałuja w sposób bardziej, a inne mniej bezpośredni. W wypadku perspektyw inflacji bank centralny formułuje wyłącznie swoją opinię jakościową. Publikacja prognoz (ilościowa) stanowi znacznie bardziej precyzyjna informację. W wypadku prognozy warunkowej punktem odniesienia jest relacja celu inflacyjnego i projekcji centralnej w horyzoncie projekcji, która podpowiada, czy bank centralny, dążąc do realizacji celu inflacyjnego, podniesie stopy procentowe, obniży czy pozostawi 
bez zmian. W wypadku prognozy bezwarunkowej stopy procentowe sa endogenizowane i społeczeństwo dowiaduje się, że spójna z prognoza jest ich zmiana albo brak zmiany. Co więcej, ścieżka stóp może zostać przedstawiona ilościowo dla całego horyzontu prognozy.

Im bardziej bezpośredni i jednoznaczny sposób przedstawiania intencji władz monetarnych, tym bardziej nasila się problem traktowania takiej informacji jako zobowiązania do określonego zachowania. Tymczasem ścieżka stóp jest tylko warunkowym (wobec założeń leżących u jego powstania) planem. Inna niż wynikająca ze ścieżki stóp zmiana oficjalnych stóp banku centralnego może obniżać wiarygodność banku centralnego. To natomiast mogłoby powstrzymywać decydentów polityki monetarnej przed innym niż ogłoszony ruchem ${ }^{4}$. Kwestie wiarygodności władz monetarnych, które nie wykonały zapowiedzianej zmiany stóp, nie dotyczą tylko przypadku publikacji ścieżki stóp procentowych. Nasilają się one już wówczas, gdy bank centralny publikuje prognozę inflacji, choćby warunkową.

Należy podkreślić, że nie tylko publikowanie prognoz inflacji budzi kontrowersje. Nastawienie także może być odmiennie interpretowane przez komitet monetarny i rynek. Nie można wykluczyć sytuacji, gdy przy nastawieniu restrykcyjnym następują obniżki stóp procentowych. Oznacza ono bowiem tylko to, że w ocenie komitetu monetarnego w momencie ogłaszania nastawienia były one mniej prawdopodobne niż obniżki.

\section{PROGNOZA INFLACJI A KSZTAETOWANIE OCZEKIWAŃ INFLACYJNYCH}

Mimo licznych kontrowersji związanych $\mathrm{z}$ publikowaniem informacji o intencjach w polityce monetarnej, większość banków centralnych wdrażających nowoczesne strategie, niekoniecznie bezpośredniego celu inflacyjnego, wykorzystuje prognozy inflacji. Obok funkcji wewnętrznych - stanowią one istotny czynnik w dyskusji o poziomie oficjalnych stóp procentowych - prognozy maja pełnić funkcje zewnętrzne. Funkcje te skoncentrowane są na oczekiwaniach inflacyjnych. Po pierwsze, wymienić należy tu kotwiczenie oczekiwań podmiotów gospodarczych, także w okresach, gdy cel inflacyjny nie jest osiągnięty ${ }^{5}$. Prowadzona $\mathrm{w}$ warunkach opóźnień polityka monetarna powinna mieć antycypacyjny charakter. Opublikowanie prognozy oznacza poinformowanie rynku, na podstawie jakich przesłanek podejmowane sa decyzje, których efekty uwidocznią się za kilka kwartałów. Ma to wpływać na bieżące oczekiwania podmiotów gospodarczych dotyczące kolejnych okresów. Te natomiast bezpośrednio przekładają się na inflację oraz na decyzje dotyczące popytu, co wpływa na lukę popytowa stanowiąca drugi, obok oczekiwań, czynnik

\footnotetext{
${ }^{4}$ G. Khan, Communicating a Policy Path: The Next Frontier in Central Bank Transparency?, Federal Reserve Bank of Kansas City, „Economic Review” Q1, 2007, s. 10.

${ }^{5}$ M. Skořepa, W. Kotlán, Assessing Future Inflation in Inflation Targeting: Forecasts or Simulations, w: Monetary Policy in Changing Environment, BIS Paper, nr 19, Basel 2003, s. 154.
} 
w równaniu inflacji ${ }^{6}$. W sytuacji standardowej to cel inflacyjny stanowić ma kotwicę nominalną. Oczekiwania inflacyjne powinny oscylować wokół poziomu celu. Gdy jednak cel okresowo jest przekroczony, publikacja prognozy ma zapobiec nadmiernemu wzrostowi oczekiwań. Po drugie, publikacja prognoz inflacji w sposób pośredni przyczynić się może do stabilizacji oczekiwań wpływa bowiem na wiarygodność banku centralnego (gdy ten publikuje dobre prognozy).

Prognoza inflacji nie jest jednak instrumentem, który w sposób bezpośredni znajdzie przełożenie na oczekiwania inflacyjne. W tabeli 2 zamieszczono listę wybranych czynników mających wpływ na percepcję prognoz inflacji przez rynek. Bank centralny nie ma wpływu na niektóre z nich. Sposób formułowania oczekiwań inflacyjnych może tylko wspierać, prowadząc skuteczną i przewidywalną politykę monetarną, nie może go jednak bezpośrednio kształtować. Odbiór prognoz związany jest również z poziomem edukacji społeczeństwa (możliwość zrozumienia zasad formułowania prognozy).

Bank centralny może natomiast wpływać na postrzeganie prognoz inflacji przez rynek przede wszystkim poprzez konsekwentne celowanie w prognozę oraz skupienie komunikacji (wyjaśniania decyzji) na prognozie inflacji. Wdrażanie nowoczesnej strategii polityki pieniężnej oznacza jednak oderwanie od wybranej zmiennej (cel pośredni) i dopuszcza patrzenie na wszystko, rozumiane jako eklektyzm w doborze argumentów stanowiących przesłankę podejmowania decyzji przez banki centralne. $\mathrm{W}$ takich ramach celowanie w prognozę jest tylko jedna $\mathrm{z}$ opcji dostępnych władzom monetarnym. Wiele banków centralnych podejmuje jednak próby realizacji celowania w prognozę, co znajduje uzasadnienie w wynikach badań wskazujących, że jest to optymalny sposób prowadzenia polityki monetarnej ${ }^{7}$. Prognoza inflacji może nawet pełnić funkcję specyficznego celu pośredniego, gdyż posiada jego cechy: jest ściśle związana $\mathrm{z}$ celem finalnym, poddaje się kontroli banku centralnego, łatwo poddaje się obserwacji ${ }^{8}$. Co więcej, prognoza powstaje $\mathrm{z}$ wykorzystaniem danych historycznych i bieżących dotyczących różnych obszarów życia gospodarczego (sfera realna, rynki finansowe, zagranica). Tym samym łączy niejako wiele zmiennych, sprowadzając je do syntetycznej informacji o przyszłym stanie gospodarki. Bank centralny, celując w prognozę, może realizować ideę patrzenia na wszystko, jednocześnie wdrażając postulat prowadzenia polityki forward-looking. Tak wykorzystywane prognozy moga ułatwić komunikację z uczestnikami rynku i zrozumienie przez nich polityki, a tym samym wpływać stabilizująco na oczekiwania inflacyjne podmiotów gospodarczych.

\footnotetext{
${ }^{6}$ Współczesną teorię ekonomiczna, która wyprowadza inflację jako zmienną zależną od dzisiejszych oczekiwań dotyczących przyszłej inflacji oraz luki popytowej, opisano m.in. w: J. Galí, Monetary Policy, Inflation, and the Business Cycle. An Introduction to the New Keynesian Framework, Princeton University Press, Princeton 2008, s. 41-52; R. Kokoszczyński, Wspótczesna polityka pieniężna w Polsce, Polskie Wydawnictwo Ekonomiczne, Warszawa 2004, s. 44-51.

${ }^{7}$ Piewca celowania w prognozę jest L. E. O. Svensson (np. Inflation Forecast Targeting: Implementing and Monitoring Inflation Targets, NBER Working Paper, nr 5797, Cambridge 1996). Taki sposób prowadzenia polityki jako optymalny sugerują również inni autorzy: K. Leitemo, Open-Economy Inflation Forecast Targeting, „German Economic Review” 7, 2006.

${ }^{8}$ G. Debelle, Inflation Targeting in Practice, Washington 1997, s. 19.
} 
Tabela 2

Czynniki wpływające na odbiór prognoz inflacji

\begin{tabular}{|c|c|}
\hline Czynnik & Charakterystyka \\
\hline $\begin{array}{l}\text { Celowanie } \\
\text { w prognozę }\end{array}$ & $\begin{array}{l}\text { Faktyczne wykorzystanie prognoz inflacji jako przesłanki } \\
\text { podejmowania decyzji przez komitet monetarny. Jeśli bank } \\
\text { centralny zadeklaruje, że decyzję o stopach procentowych } \\
\text { podejmuje, wykorzystując prognozy inflacji i faktycznie taka } \\
\text { regułę realizuje, a także akcentuje to w komunikacji (wy- } \\
\text { jaśnienia decyzji), to podmioty gospodarcze powinny być } \\
\text { skłonne wykorzystywać prognozę, formułując swoje } \\
\text { oczekiwania. }\end{array}$ \\
\hline $\begin{array}{l}\text { Częstotliwość } \\
\text { sporzadzania } \\
\text { prognoz }\end{array}$ & $\begin{array}{l}\text { Relacja częstotliwości sporządzania prognoz do posiedzeń } \\
\text { decyzyjnych, na których jest ona rozpatrywana (do czasu } \\
\text { ukazania się kolejnej prognozy). Gdy informacja publiczna } \\
\text { ukazuje się z niska częstotliwościa, oczekiwania podmiotów } \\
\text { gospodarczych stają się bardziej heterogeniczne, szczególnie } \\
\text { wobec faktu, że na kolejnych posiedzeniach (gdy nie ma nowej } \\
\text { prognozy) komitet monetarny będzie koncentrował dyskusję } \\
\text { wokół czynników bieżących. Nie ma możliwości sporządzania } \\
\text { prognoz w okresach częstszych niż kwartalne (rachunki } \\
\text { narodowe ukazują się kwartalnie). }\end{array}$ \\
\hline $\begin{array}{l}\text { Sposób formułowania } \\
\text { oczekiwań }\end{array}$ & $\begin{array}{l}\text { Większość badań empirycznych nie potwierdza hipotezy } \\
\text { o racjonalnym formułowaniu oczekiwań przez podmioty gos- } \\
\text { podarcze. Sa one zazwyczaj w mniejszym lub większym stopniu } \\
\text { adaptacyjne. Uwzględnianie prognoz inflacji w oczekiwaniach } \\
\text { zależy od tego, w jakim stopniu podmioty sa antycypacyjne. }\end{array}$ \\
\hline Rodzaj prognozy & $\begin{array}{l}\text { Wybór między prognozą warunkową a bezwarunkową. } \\
\text { W pierwszym wypadku społeczeństwo nie rozumie szczególnego } \\
\text { założenia leżącego u podstaw jej sformułowania. Ujawnienie } \\
\text { funkcji reakcji (prognoza bezwarunkowa) oznacza przyznanie, } \\
\text { że bank centralny realizuje inne cele niż cel inflacyjny. } \\
\text { W wypadku publikacji ścieżki stóp może być ona traktowana } \\
\text { jako szczególnie silne zobowiązanie. }\end{array}$ \\
\hline
\end{tabular}

Źródło: opracowanie własne.

Mimo przedstawionych zalet celowania w prognozę, nie wszystkie banki centralne, prowadząc politykę pieniężną, opierają się na prognozie inflacji z jednakową konsekwencja. Trudno wskazać czynniki, jakie determinuja zachowanie banku centralnego w tym obszarze ${ }^{9}$. Jednym z warunków konsekwentnego celowania w prognozę jest jednak wdrażanie pełnej wersji strategii celu inflacyjnego, co wyklucza konieczność koncentracji na innych celach (na

${ }^{9}$ Autorka przeprowadziła badania dotyczące konsekwencji celowania w prognozę przez 4 kraje Europy Środkowo-Wschodniej (Polska, Czechy, Węgry i Słowacja) obejmujące lata 2001-2008. Wskazały one, że najbardziej konsekwentnie w prognozę celował Narodowy Bank Czech. Najmniej konsekwentnie - Narodowy Bank Węgier. M. Szyszko, Prognozowanie inflacji w polityce pieniężnej, C. H. Beck, Warszawa 2009. 
Tabela 3

Rodzaj prognozy a jej odbiór przez uczestników rynku

\begin{tabular}{|c|c|c|c|}
\hline $\begin{array}{l}\text { Rodzaj } \\
\text { prognozy }\end{array}$ & \multicolumn{2}{|c|}{ Warunkowa } & Bezwarunkowa \\
\hline Istota & \multicolumn{2}{|c|}{$\begin{array}{l}\text { Założenie o stałości } \\
\text { stóp procentowych }\end{array}$} & $\begin{array}{c}\text { Stopy procentowe endogenizowane; } \\
\text { funkcja reakcji zgodna z formułą } \\
\text { reguły Taylora }\end{array}$ \\
\hline $\begin{array}{c}\text { Punkt } \\
\text { odniesienia }\end{array}$ & \multicolumn{2}{|c|}{$\begin{array}{c}\text { Projekcja centralna: relacja ścieżki } \\
\text { centralnej do celu inflacyjnego }\end{array}$} & Scieżka stóp procentowych \\
\hline \multirow{4}{*}{ Interpretacja } & $\begin{array}{l}\text { projekcja } \\
\text { centralna: }\end{array}$ & $\begin{array}{c}\text { stopy } \\
\text { procentowe: }\end{array}$ & \multirow{4}{*}{$\begin{array}{l}\text { Zamian stóp w kolejnych okresach } \\
\text { wynika bezpośrednio ze ścieżki }\end{array}$} \\
\hline & poniżej celu & spadek & \\
\hline & na poziomie celu & bez zmian & \\
\hline & powyżej celu & wzrost & \\
\hline Perspektywa & \multicolumn{2}{|c|}{ Transmisji monetarnej } & Najbliższy okres \\
\hline
\end{tabular}

Źródło: opracowanie własne.

przykład celu kursowym), które okresowo mogłyby stać się priorytetowe. Decydujące znaczenie ma jednak postawa komitetu monetarnego, który chce wdrażać taką regułę. Decyzje podejmuje wówczas w momencie, gdy prognoza jest najbardziej aktualna, nie widzi podstaw do przyjmowania pozycji wait and see lub do analizy zwiększonego okresowo ryzyka prognozy ${ }^{10}$.

Konsekwentne celowanie w prognozę powinno mieć jednoznaczne przełożenie na możliwość wykorzystania tej informacji w formułowanych oczekiwaniach. Podmioty gospodarcze, znając rolę prognozy w procesie decyzyjnym, mogą na jej podstawie formułować oczekiwania dotyczące przyszłego ruchu władz monetarnych i ścieżki inflacji. Ponownie podkreślić należy, że systematyczne celowanie w prognozę jest tylko jednym z czynników mogących wesprzeć rolę prognozy jako głównego komponentu oczekiwań. Jeśli te oczekiwania sa przede wszystkim adaptacyjne, to prognoza i tak nie będzie miała pierwszorzędnego znaczenia ${ }^{11}$.

${ }^{10}$ Tak zachowywał się Narodowy Bank Czech, celując w prognozę konsekwentnie nawet w okresie, gdy na rynkach w krajach regionu uwidaczniały się z największą ostrością skutki kryzysu finansowego (przełom 2008 i 2009 r.).

${ }^{11}$ Badania empiryczne wskazują, że oczekiwania inflacyjne sa przynajmniej w części adaptacyjne. Badania na ten temat przedstawiono m.in. w: T. Łyziak, Consumer Inflation Expectations in Poland, ECB Working Paper Series, Working Paper, nr 287, 2003; M. Forsells, G. Kenny, The Rationality of Consumers' Inflation Expectations: Survey-Based Evidence for the Euro Area, ECB Working Papers Series, Working Paper, nr 163, 2002; Ch. Gerberding, The Information Content of Survey Data on Expected Price Developments for Monetary Policy, Discussion Paper 9/01, Economic Research Center of the Deutsche Bundesbank, Frankfurt am Main 2001. 
W tabeli 2 wspomniano również o rodzaju prognozy jako o czynniku wpływającym na jej odbiór i zrozumienie. W tabeli 3 zawarto syntetyczne zestawienie, w jaki sposób prognoza powinna być odczytywana i interpretowana.

Prognozy są interpretowane w sposób przedstawiony w tabeli 3 właściwie tylko przez wąską grupę analityków i specjalistów. Reszta społeczeństwa to niejako wtórni odbiorcy prognoz, którzy nie odwołują się bezpośrednio do publikacji banku centralnego, ale korzystają właśnie z komentarzy analityków. Nawet wówczas taki czynnik, jak szczególne założenie leżące u podstaw sformułowania prognozy warunkowej może nie być prawidłowo odczytywany. Uczestnicy życia gospodarczego nie rozumieją również, jaką perspektywę należy brać pod uwagę w wypadku obu prognoz. Przy prognozie warunkowej, ze względu na opóźnienia, relacja projekcji centralnej do celu w horyzoncie transmisji monetarnej będzie kluczowa przy podejmowaniu decyzji o poziomie stóp. W wypadku ścieżki stóp najważniejszy jest najbliższy okres (zasadniczo do czasu ukazania się nowej prognozy). Podejmowanie decyzji dla kilku następnych okresów tuż po sporządzeniu prognozy jest niezgodne z przyjętymi procedurami decyzyjnymi. Zresztą badania empiryczne potwierdzaja niska wartość już średniookresowych prognoz stóp ${ }^{12}$. Kształtowanie oczekiwań na poziomie pożądanym przez bank centralnym uwarunkowane jest więc zrozumieniem prognoz, co niekoniecznie ma miejsce. Co więcej, nawet prawidłowo interpretowana prognoza (ścieżka stóp) nie będzie dokładnie prowadziła rynku. Praktyka w wielu krajach sprowadza się do zmian stóp banku centralnego w wysokości 25 punktów bazowych lub, w wyjątkowych sytuacjach, wielokrotności 25 punktów bazowych, tymczasem bank centralny może celować w poziom 2,6\% wybranej stawki rynku międzybankowego. Prognoza inflacji nie naprowadzi rynku na taki poziom. Sytuacja ta nabiera szczególnego znaczenia w obszarach monetarnych, w których proces dezinflacji został zakończony, a inflacja i stopy procentowe utrzymuja się na niskich (bliskich zeru) poziomach. Dyskrecjonalne zmiany stawek rynku międzybankowego moga być wówczas pożądane dla bankiera centralnego ${ }^{13}$.

W kontekście wpływu prognoz na oczekiwania należy wskazać, że jednak większą siłę oddziaływania może mieć tu prognoza bezwarunkowa, i to z opublikowaną numerycznie ścieżką stóp. Wskazuje się, że publikacja ścieżki:

- podkreśla zaangażowanie banku centralnego w realizację długoterminowych celów, jeśli obok celów ogłasza się konkretne, łatwo weryfikowalne sposoby ich osiągania (ścieżkę zmiany stóp);

${ }^{12}$ W opracowaniu Ch. A. E. Goodhart, W. Bin Lim, Interest Rate Forecast - A Pathology, ,International Journal of Central Banking" 2011, June, stwierdzono na podstawie badań empirycznych, że ścieżka stóp była spójna z ruchami władz monetarnych w pierwszym kwartale, a po jej opublikowaniu, co najwyżej w drugim. Powyżej 6 miesięcy stopy zmieniano niezależnie od ścieżki zaprezentowanej pół roku wcześniej. Jest to zgodne z częstotliwością ukazywania się prognoz, zazwyczaj kwartalną lub czteromiesięczną: prognoza stóp obowiązuje niejako do czasu ukazania się kolejnej prognozy.

${ }^{13}$ M. Szyszko, Wptyw publikacji prognoz banku centralnego na zmienność stóp procentowych rynku międzybankowego, w: E. Gruszczyńska-Brożbar (red.), Rynek kapitatów pieniężnych. Wybrane zagadnienia, Zeszyty Naukowe Uniwersytetu Ekonomicznego w Poznaniu, nr 164, Wydawnictwo Uniwersytetu Ekonomicznego w Poznaniu, Poznań 2010, s. 30. 
- umożliwia bardziej efektywną wycenę aktywów finansowych na rynkach, ponieważ lepiej pozwala kotwiczyć również krótkoterminowe oczekiwania;

- daje władzom monetarnym większy wpływ na długoterminowe stopy procentowe (założywszy, że związki między stopami krótko- i długoterminowymi tłumaczy teoria oczekiwań) ${ }^{14}$.

Dwie pierwsze zalety publikacji ścieżki stóp mają związek z tym, że jeśli społeczeństwo jej nie zna, to jedynym punktem odniesienia jest dla niego deklaracja dotycząca celu inflacyjnego, która zrealizowana ma zostać w średnim horyzoncie. Wpływ na stopy długoterminowe jest natomiast istotny ze względu na to, że podmioty gospodarcze kierują się poziomem stopy długoterminowej, podejmując decyzje, a bank centralny bezpośrednio może oddziaływać tylko na stopę krótkoterminową.

Niemniej jednak istnieją również argumenty przeciwko publikacji ścieżki stóp procentowych. Jeden $\mathrm{z}$ nich - niezgodność $\mathrm{z}$ procedurami decyzyjnymi komitetów monetarnych i niska sprawdzalność nawet średnioterminowych ścieżek - został już przytoczony. Z punktu widzenia wpływu na oczekiwania inflacyjne należy rozważyć jeszcze dwa. Po pierwsze, im bardziej jednoznaczny sposób komunikowania intencji banku centralnego (a ścieżka stóp jest tu najbardziej jednoznaczną formą), tym większe prawdopodobieństwo, że społeczeństwo odbierze informacje jako zobowiązanie. Celowanie w prognozę jest tymczasem elastyczną reguła polityki i bank centralny ma prawo znaleźć bardziej przekonujące przesłanki decyzyjne (co zresztą zgodne jest $\mathrm{z}$ idea patrzenia na wszystko). Co więcej, publikacja ścieżki przynosi relatywnie małe korzyści marginalne w porównaniu z publikacja prognozy. Oszacowanie równań makroekonomicznych (krzywej IS i krzywej Phillipsa) stanowi dla podmiotów wyzwanie ze względu na duże skomplikowanie tych równań i znaczne zaburzenia zwiększające wariancję estymatorów. Pomoc, jakiej może udzielić podmiotom bank centralny $\mathrm{w}$ zakresie oszacowania równań makroekonomicznych, jest zatem bardzo ważna. Jeśli jednak podmioty dzięki pomocy banku centralnego $\mathrm{w}$ miarę dobrze poznają strukturę gospodarki i, co za tym idzie, stosunkowo precyzyjnie potrafią prognozować inflację oraz lukę popytowa, ustalenie najbardziej prawdopodobnego sposobu reagowania przez bank centralny nie nastręcza już dużych trudności. Z wyjątkiem sytuacji nadzwyczajnych, takich jak obserwowane w ostatnim okresie zawirowania na rynkach finansowych, polityka banków centralnych jest dość dobrze przewidywalna ${ }^{15}$. Dlatego publikowanie prognozy warunkowej wydaje się wystarczające z punktu widzenia kształtowania oczekiwań. Potwierdza to raczej wolno rosnąca liczba krajów, które publikują ścieżkę stóp przy powszechnym sporządzaniu prognoz inflacji. Jednak wnioski te można skonfrontować z oceną wpływu ścieżki stóp na oczekiwania rynku w Norwegii. Badania przeprowadzone w 2008 r., po trzech latach publikacji ścieżki stóp, wskazuja, że zmniejszyła się zmienność rynkowych stóp procentowych w dniu ogłoszenia decyzji o zmianie stóp, co sugeruje, iż precyzyjniejsze komunikowanie intencji banku centralnego poprawia zrozumienie przez uczestników życia gospodarczego sposobu reakcji banku

\footnotetext{
${ }^{14}$ G. Khan, op. cit., s. 5-10.

${ }_{15}$ M. Brzoza-Brzezina, Korzyści z publikacji projekcji makroekonomicznych i ścieżki stóp procentowych w Polsce, „Bank i Kredyt” 2008, nr 12, s. 8-10.
} 
centralnego ${ }^{16}$. Kwestią oczywista jest, że bezpośrednie porównywanie tych badań nie jest możliwe. Wskazują one jednak na to, że bank centralny może uzasadnić swoją politykę komunikacyjną, odwołując się do różnych aspektów.

Z przedstawionych powyżej rozważań wynika, że możliwość kotwiczenia oczekiwań poprzez publikację prognoz inflacji nie jest jednoznaczna. Zależy od różnych czynników leżących w znacznej mierze poza wpływem banku centralnego. Teoria jednak przypisuje prognozom właśnie rolę czynnika wspomagającego prowadzenie polityki monetarnej nakierowanej na oczekiwania, a banki centralne próbuja wykorzystać je w tej roli. Dlatego w kolejnej części opracowania przedstawione zostaną wyniki badań na temat faktycznych współzależności między wynikami prognoz inflacji a oczekiwaniami.

\section{SKUTECZNOŚĆ PROGNOZ W ŚWIETLE BADAŃ}

Wpływ komunikacji z rynkiem na stabilizowanie oczekiwań inflacyjnych był przedmiotem licznych analiz teoretycznych i empirycznych. Badania, których wyniki przedstawiano poniżej, wykorzystują różne metody, odnoszą się również do różnych okresów i mają odmienne zakresy terytorialne w przypadku badań empirycznych. Należy je traktować jako przegląd literatury na temat relacji między prognozą inflacji a oczekiwaniami inflacyjnymi. Nieliczne badania odnoszą się przy tym bezpośrednio do współzależności między prognozami inflacji a oczekiwaniami inflacyjnymi. Większość koncentruje się na wpływie przejrzystości (utożsamianej z jakimś sposobem publikowania prognoz przez bank centralny) na wyniki gospodarki. Badacze, których prace zaprezentowano w tabeli 4, wpisują się w ekonomię głównego nurtu. Oznacza to akceptację ram nowej syntezy neoklasycznej i zgodnego z nimi rozumienia procesów gospodarczych. Dlatego nawet jeśli nie odwołują się explicite do oczekiwań inflacyjnych, to zakładają, że opublikowanie (bądź nie) dodatkowej informacji wpływa na decyzje podmiotów gospodarczych co do przyszłych wyborów. Z czasem ewoluowały jednak założenia modeli. Najnowsze prace analizuja kwestię wpływu informacji na rynek przez pryzmat adaptacyjnego uczenia się i wiedzy niedoskonałej.

Badania empiryczne relacji między prognozami inflacji a innymi aspektami są utrudnione. Jest to uwarunkowane szeregiem czynników. Po pierwsze banki centralne zmieniaja w czasie sposób publikowania wyników prognoz, dlatego jednolite szeregi czasowe sa stosunkowo krótkie. Po drugie, sposób publikacji wyników prognoz nie zawsze jest jednoznaczny. Jedna ze zmiennych w badaniu jest więc zmienną jakościową, co utrudnia badania ilościowe. Podejmuje się próby pomiaru stopnia przejrzystości systemu prognozowania inflacji, a także innych ujęć uwzględniania informacji o wyniku prognoz.

To pierwsze podejście zastosowano w badaniu obejmującym próbę 87 krajów i odwołującym się do drugiej połowy lat 90. Przejrzystość systemu prognozowania zmierzono $\mathrm{z}$ wykorzystaniem prostego indeksu opartego na skali

${ }^{16}$ A. Holmsen, J. F. Qvigstad, Ø. Røisland, K. Solberg-Johansen, Communicating Monetary Policy Intentions: The Case of Norges Bank, Norges Bank Working Paper 2008, nr 20. 
Guttmana. Stwierdzono istnienie ujemnej korelacji między poziomem przejrzystości polityki monetarnej $\mathrm{w}$ obszarze prognozowania a inflacją. Publikacja szerszego zakresu informacji o prognozach miała również redukować skrzywienie inflacyjne czy minimalizować funkcję strat banku centralnego ${ }^{17}$.

Inna grupa badań testuje bezpośrednio współzależności między prognozami inflacji a oczekiwaniami inflacyjnymi. Oczekiwania sa zmienną nieobserwowalną bezpośrednio. Informacje o ich poziomie można czerpać z rynków finansowych (ceny aktywów) lub z sondaży (oczekiwania inflacyjne osób fizycznych, przedsiębiorstw, specjalistów). W tym pierwszym przypadku analizuje się wpływ ujawnienia informacji (decyzja, prognoza) na rynkowe stopy procentowe. Efekt informacji jest więc krótkoterminowy. Badania te prowadzą do podobnych wniosków: zwiększanie stopnia przejrzystości redukuje wpływ polityki monetarnej na rynki finansowe. Wpływ decyzji na krótki koniec krzywej dochodowości zmniejszył się, a zmienność cen aktywów - również. Polityka pieniężna jest bardziej przewidywalna ${ }^{18}$. Wnioski te są zgodne $\mathrm{z}$ wynikami badań dotyczącymi wpływu publikacji ścieżki stóp na stopy rynkowe, sporządzonymi dla Norwegii i opisanymi pokrótce w poprzedniej części opracowania.

Badania dotyczące współzależności między prognozami inflacji a oczekiwaniami inflacyjnymi pozyskiwanymi w sondażach są nieliczne. Wskazują one na istnienie istotnych statystycznie współzależności między wynikiem prognozy a oczekiwaniami inflacyjnymi o co najwyżej średniej sile. Siła ta zależy między innymi od opóźnień i sposobu zakodowania danych. Co więcej, wyniki badań sugeruja, że osoby fizyczne w zasadzie nie rozumieją prognoz inflacji: pozyskane statystyki maja znak dodatni, co sugeruje jednokierunkową zmianę (na przykład sytuacji, w której ścieżka centralna jest powyżej celu inflacyjnego, towarzyszy wzrost oczekiwań inflacyjnych). Oznacza to, że w formułowanych oczekiwaniach nie uwzględniają one tego, że w reakcji na prognozę inflacji bank centralny zmieni stopy procentowe i doprowadzi do powrotu inflacji do poziomu docelowego w horyzoncie transmisji monetarnej. Wśród 4 badanych krajów $\mathrm{w}$ jednym sporządzano prognozę bezwarunkowa (Czechy). W tym przypadku także znaki współczynników wskazywały na jednokierunkową zmianę sugerowanych stóp procentowych i inflacji ${ }^{19}$. Takie wyniki wyjaśniać może również fakt, że uwzględnienie prognoz inflacji $\mathrm{w}$ formułowanych oczekiwaniach wymagałoby, by konsumenci formułowali oczekiwania w sposób racjonalny. Badania dowodzą, że nie jest to standardem.

Przegląd wyników badań pozwala na wyciągnięcie kilku wniosków. Po pierwsze, możliwość sterowania oczekiwaniami inflacyjnymi przez bank centralny dzięki publikacji prognoz inflacji jest ograniczona. Źródła tego ograniczenia leżą w znacznej mierze poza kontrolą banku centralnego. Po drugie mechanizm przełożenia wyniku prognoz na oczekiwania nie jest dobrze zidentyfikowany, a do tego zmienia się w czasie. Po trzecie, oczekiwania nie sa

17 G. Chortareas, D. Stasavage, G. Sterne, Does It Pay to Be Transparent? International Evidence from Central Bank Forecasts, The Federal Reserve Bank of St. Louis, St. Louis 2002, s. 8.

${ }^{18}$ S. Eijffinger, P. M. Geraats, C. A. B. van der Cruijsen, Does Central Bank Transparency Reduce Interest Rates?, CEPR Discussion Papers 5526, 2006, s. 4.

${ }^{19}$ M. Szyszko, The Interdependences of Central Bank's Forecasts and Economic Agents Inflation Expectations: Empirical Study, National Bank of Poland Working Paper, nr 105, NBP, Warsaw 2011. 


\section{Tabela 4}

Wpływ publikacji prognoz inflacji na wyniki gospodarki

\begin{tabular}{|c|c|c|}
\hline Autorzy & Model & Wnioski \\
\hline Faust, Svensson & $\begin{array}{l}\text { zmodyfikowany Barro- } \\
\text {-Gordona }\end{array}$ & $\begin{array}{l}\text { Wysoki stopień przejrzystości poprawia do- } \\
\text { brobyt, redukuje skrzywienie inflacyjne } \\
\text { oraz zmienność produktu i zatrudnienia. }\end{array}$ \\
\hline Jensen & $\begin{array}{l}\text { uwzględniający mono- } \\
\text { polistyczną konkuren- } \\
\text { cję i niejednoczesną } \\
\text { zmianę cen }\end{array}$ & $\begin{array}{l}\text { Wzrastająca przejrzystość zwiększa dyscy- } \\
\text { plinę i wiarygodność banku centralnego, } \\
\text { gdyż wraz z nią wzrastają potencjalne kosz- } \\
\text { ty utraty reputacji przez bank centralny. }\end{array}$ \\
\hline Cukiermann & $\begin{array}{l}\text { model Barro-Gordona } \\
\text { i model neokeynesowski }\end{array}$ & $\begin{array}{l}\text { Wyniki zależa od modelu i od tego, czy } \\
\text { prognoza zostanie opublikowana przed za- } \\
\text { kończeniem formułowania oczekiwań, czy } \\
\text { po; w obu modelach preferowana jest ogra- } \\
\text { niczona przejrzystość. }\end{array}$ \\
\hline Geraats & model Barro-Gordona & $\begin{array}{l}\text { Publikacja prognozy redukuje zmienność } \\
\text { inflacji, ale wpływ na produkt nie jest } \\
\text { jednoznaczny, wpływ prognozy bezwarun- } \\
\text { kowej jest mniejszy. }\end{array}$ \\
\hline $\begin{array}{l}\text { Chorateas, } \\
\text { Stasavage, Stern }\end{array}$ & model Barro-Gordona & $\begin{array}{l}\text { Wyższa przejrzystość (rozumiana między } \\
\text { innymi jako publikacja prognoz przez bank } \\
\text { centralny) prowadzi do redukcji współ- } \\
\text { czynnika poświęcenia, zimniejsza wymien- } \\
\text { ność między inflacją a produktem, prowa- } \\
\text { dząc do szybszego dostosowywania się } \\
\text { oczekiwań. }\end{array}$ \\
\hline $\begin{array}{l}\text { Dale, Orphanides, } \\
\text { Österholm }\end{array}$ & $\begin{array}{l}\text { stylizowany model gos- } \\
\text { podarki eksponujacy } \\
\text { adaptacyjne uczenie się }\end{array}$ & $\begin{array}{l}\text { Wzrost przejrzystości może również pro- } \\
\text { wadzić do zakłóceń i niepewności; zależy to } \\
\text { od stopnia zrozumienia informacji przez } \\
\text { społeczeństwo. }\end{array}$ \\
\hline Brzoza-Brzezina & $\begin{array}{l}\text { nowokeynesowski mo- } \\
\text { del gospodarki polskiej }\end{array}$ & $\begin{array}{l}\text { Zwiększenie przejrzystości (publikacja } \\
\text { prognoz) jest zawsze korzystne i prowadzi } \\
\text { do obniżenia wartości funkcji start banku } \\
\text { centralnego, przy czym korzyści z publikacji } \\
\text { projekcji znaczaco przewyższaja korzyści } \\
\text { z publikacji dodatkowo ścieżki stóp. }\end{array}$ \\
\hline
\end{tabular}

Źródło: opracowanie własne na podstawie: M. Brzoza-Brzezina, Polska polityka pieniężna. Badania teoretyczne i empiryczne, C. H. Beck, Warszawa 2011; G. Chortareas, D. Stasavage, G. Sterne, op. cit.; S. Dale, A. Orphanides, P. Österholm, Imperfect Central Bank Communication: Information versus Distraction, „International Journal of Central Banking” 2011, June; J. Faust, L. E. O. Svensson, The Equilibrium Degree of Transparency and Control in Monetary Policy, Discussion Paper, nr 2195, Centre for Economic Policy, Research, October 2000; M. P. Geraats, Why Adopt Transparency? The Publication of the Central Bank Forecast, ECB Working Paper, nr 41, Frankfurt am Main 2001; H. Jensen, Optimal Degrees of Transparency in Monetary Policymaking, Working Paper of University of Copenhagen, Copenhagen 2000; A. Cukierman, Establishing a Reputation for Dependability by Means of Inflation Targets, w: L. Mahadeva, G. Sterne (red.), Monetary Frameworks in a Global Context, Routledge, London 2000. 
homogeniczne i różne grupy podmiotów inaczej będą reagować na wyniki prognoz. Uprzywilejowani (pod względem zrozumienia prognoz) są specjaliści. Po czwarte, brak jednoznacznych wyników badań dotyczących tych zagadnień może być związany nie tyle $\mathrm{z}$ brakiem faktycznego wpływu prognoz na oczekiwania podmiotów gospodarczych, ile z niedostatkiem narzędzi badawczych. Przykładowo, modele szkoły głównego nurtu, na których opiera się analiza, poddawane są krytyce. Te konkluzje nie zniechęcaja jednak banków centralnych do wdrażania spójnej strategii komunikacji i coraz większej otwartości polityki pieniężnej. Prognozy inflacji publikowane są już powszechnie, dodatkowo rośnie grupa krajów sporządzających prognozy bezwarunkowe i publikujących ścieżkę stóp.

\section{PODSUMOWANIE}

Sygnalizowanie intencji banku centralnego ma wpływ na oczekiwania podmiotów gospodarczych. Jest to istotny argument za zwiększaniem przejrzystości działań banków centralnych, co ma miejsce w ostatnich dziesięcioleciach. Najbardziej zaawansowanym sposobem sygnalizowania intencji sa prognozy inflacji. Ich wpływ na oczekiwania inflacyjne, na ceny aktywów, a nawet wyniki gospodarki w skali makro jest przedmiotem licznych badań. Ich wyniki nie są jednoznaczne. Mimo to większość banków centralnych publikuje prognozy, a niekiedy nawet ścieżkę stóp. Ten ostatni krok wydaje się zreszta kolejnym wymiarem przejrzystości polityki pieniężnej, jaki realizować będa banki centralne.

Sygnalizowanie intencji jest jednak wyzwaniem dla banków centralnych. Jak podkreślono, nie ma on bezpośredniego wpływu na przełożenie wyników prognoz na oczekiwania inflacyjne i kolejno - inne zmienne. Realizując konsekwentnie spójną strategię komunikacji, może wspierać ten proces. Jednym z możliwych sposobów wsparcia jest spójność deklaracji banku centralnego (miejsce prognoz w systemie decyzyjnym) z faktycznymi działaniami. Sygnał (prognoza) powinien być również publikowany ze znaczną częstotliwością. Nie można jednak dostosować częstotliwości sporządzania prognoz do kalendarza obrad komitetów monetarnych. Do tych ograniczeń, z których część leży poza kontrolą banku centralnego, należy dostosować strategię komunikacji i ewentualnie modyfikować ja. Zmiana strategii komunikacji wymusza również na władzach monetarnych zmianę zachowania. Opublikowanie projekcji bądź ścieżki stóp wpływa na zmianę zachowania podmiotów i tym samym wymusza zmianę polityki stopy procentowej przez bank centralny. Jeśli bank nie dostosuje polityki stóp procentowych do polityki informacyjnej, musi się liczyć z utratą części korzyści, które niesie zwiększenie przejrzystości. Wynik ten wskazuje na potencjalne korzyści, jakie może osiągnąć bank centralny, badając sposób formułowania oczekiwań przez podmioty ${ }^{20}$.

Wskazać należy również na to, że informacja o intencjach nie jest jedyną publikowaną przez banki centralne. Większość z nich publikuje całościowe

${ }^{20}$ M. Brzoza-Brzezina, Korzyści..., s. 10. 
oceny bieżącej sytuacji gospodarczej takich w dokumentach, jak raporty o inflacji. Do tego ujawnia się opisy dyskusji na posiedzeniach komitetów monetarnych. Obok oficjalnych informacji banku centralnego, rynek wyciaga wnioski na temat intencji na podstawie innych analiz, o mniej formalnym charakterze $^{21}$. Uczestnicy rynku finansowego moga też, w sytuacji gdy otoczenie charakteryzuje się zwiększoną zmiennością i niepewnością, aktywnie wykorzystywać konferencje prasowe w celu pozyskiwania dodatkowych informacji ${ }^{22}$.

Dodatkowo pojawić się może problem dostosowywania komunikacji do czasowo zmienionych ram działania banku centralnego. Przykładem niech będzie okres prowadzenia polityki monetarnej z wykorzystaniem poluzowania ilościowego, które zastąpić miało tradycyjne (nieefektywne) oddziaływanie kanałem stopy procentowej. W okresie tym niektóre banki centralne sygnalizowały, że model prognostyczny jest nieadekwatny i prognoza nie może stanowić głównej przesłanki podejmowania decyzji przez komitet monetarny. W ostatnich latach uczestnicy rynku stanęli wobec konieczności zrewidowania sposobu formułowania oczekiwań, w tym zakresu uwzględnianych informacji.

Badanie tego aspektu polityki monetarnej, jakim jest związek między sposobem komunikowania intencji przez bank centralny a oczekiwaniami inflacyjnymi podmiotów gospodarczych, musi zostać pogłębione w wielu wymiarych. Jednym $\mathrm{z}$ nich jest sformalizowanie pomiaru sposobu ujawniania prognoz i informacji związanych z ich tworzeniem. Przejrzystość jako aspekt jakościowy jest $\mathrm{z}$ natury trudno mierzalna, sensowny jej pomiar ${ }^{23}$ mógłby jednak ułatwić porównania między krajami i wyciąganie wniosków dotyczących relacji między sposobem publikowania prognoz a oczekiwaniami. Jak już sygnalizowano, badania te utrudnia właśnie charakter dostępnych danych, które w znacznej mierze są jakościowe.

dr Magdalena Szyszko

Wyższa Szkoła Bankowa w Poznaniu

magdalena.szyszko@wsb.poznan.pl

${ }^{21}$ Znaczenie może mieć np. charakter i pozycja w gremium członka komitetu monetarnego, który wypowiada się na temat kształtu procesów gospodarczych. M. Rozkrut, It's Not only WHAT Is Said, It's also WHO the Speaker Is. Evaluating the Effectiveness of Central Bank Communication, National Bank of Poland Working Paper, nr 47, NBP, Warsaw 2008.

${ }^{22}$ Co pokazują badania przeprowadzone dla Europejskiego Banku Centralnego, M. Ehrmann, M. Fratzscher, Explaining Monetary Policy in Press Conferences, „International Journal of Central Banking" 2009, June.

${ }^{23}$ Takie próby sa podejmowane. Wskaźnik oparty na skali Guttmana nie jest jednak satysfakcjonujący, a indeks Eijffingera-Geraats zbyt szeroki, by jednoznacznie wyciąać wnioski na temat przejrzystości systemu prognozowania (tylko) i innych zmiennych. W pracy M. Szyszko, Prognozowanie..., zaproponowano wstępną koncepcję takiego miernika, musiałaby ona zostać zaktualizowana choćby w związku z coraz powszechniejszą praktyką publikacji ścieżki stóp. 


\title{
THE CENTRAL BANK'S COMMUNICATION WITH THE MARKET AND STABILISATION OF INFLATION EXPECTATIONS
}

\begin{abstract}
Summary
The paper focuses on the central bank's optimal communication with the market participants, and analyses the impact of the disclosure of the central bank's intentions on the expectations of the economic agents. The stabilisation of inflation expectations is the main task of the monetary authorities. The main purpose of the paper is to analyse the relationship between the central bank forecasts and expectations. The text is organised as follows: section II describes the ways in which central banks signal their future policy actions. The inflation forecasts as tools influencing the expectations are described in section III. Section IV, in turn, provides an overview of the theoretical and empirical research on inflation forecasts, expectations and other economic variables. The paper also contains the description of pros and cons of publishing the policy path. The analysis of the research together with practical aspects does not lead to any explicit conclusions on the interdependences of inflation forecasts and expectations. The influence of the central bank forecasts is diverse and varies over time. However, central banks include a forecast disclosure in their communication strategy because of its potential advantages.
\end{abstract}

